\title{
Anti-atherosclerotic activity of n-Hexane extract of Eleutherine americana Merr. on human macrophage primary cell culture
}

\author{
Siti Khotimah ${ }^{1,2 *}$, Handono Kalim ${ }^{3}$, Mohammad Saifur Rohman ${ }^{4}$, Setyawati Soeharto ${ }^{5}$ \\ ${ }^{1}$ Doctoral Program of Medical Science, Faculty of Medicine, Universitas Brawijaya, Malang, Jawa Timur, Indonesia. \\ ${ }^{2}$ Department of Biochemistry, Medical Faculty of Mulawarman University, Samarinda, Kalimantan Timur, Indonesia. \\ ${ }^{3}$ Division of Rheumatology and Immunology, Department of Internal Medicine, Saiful Anwar General Hospital, Faculty of Medicine, \\ Universitas Brawijaya, Malang, Jawa Timur, Indonesia. \\ ${ }^{4}$ Division of Cardiology and Vascular Medicine, Faculty of Medicine, Universitas Brawijaya, Malang, Jawa Timur, Indonesia. \\ ${ }^{5}$ Department of Pharmacology, Faculty of Medicine, Universitas Brawijaya, Malang, Jawa timur, Indonesia.
}

\begin{tabular}{l}
\hline ARTICLE INFO \\
\hline Received on: 09/10/2019 \\
Accepted on: 13/12/2019 \\
Available online: 05/03/2020 \\
\\
\hline Key words: \\
Eleutherine americana Merr., \\
foam cell, TLR4, ABCA1, \\
ABCG1.
\end{tabular}

\begin{abstract}
Atherosclerosis, a chronic disorder and the main pathogenesis of various cardiovascular diseases, is initiated by the formation of the macrophage foam cell at the subendothelial layer of the blood vessel wall. This study aimed to investigate the anti-atherosclerosis activity of n-hexane extract of Eleutherine americana Merr. (E. americana) on human macrophage through in vitro induction with oxidized-Low Density Lipoprotein (ox-LDL). The macrophage was obtained from peripheral blood mononuclear cells (PBMCs) that were isolated from the serum of a healthy male. After the monocytes were maturely differentiated, the n-hexane extract of E. americana with a dose of $0.25,1$, and $2 \mathrm{mg} / \mathrm{ml}$ was added before stimulation with ox-LDL. The foam cell was determined through Oil Red O staining, the expressions of Toll-Like Receptor 4 (TLR4) and Adenosine Triphosphate-binding cassette transporter A1/G1 (ABCA1/ ABCG1) were measured by immunofluorescence, and the activity of peroxisome-proliferator-activator receptor $\gamma$ (PPAR $\gamma$ ) was measured through Enzyme-linked immunosorbent assay. The results demonstrated that the foam cell and the expression of TLR4 on the group with E. americana extract treatment were lower than the ox-LDL group $(p<$ $0.05)$. The expression of ABCA1 and ABCG1 on the group that was given the extract was higher than ox-LDL group $(p<0.05)$. This study concluded that the n-hexane extract of $E$. americana demonstrated anti-atherosclerosis activity on human macrophage induced with ox-LDL.
\end{abstract}

\section{INTRODUCTION}

Cardiovascular disease is the leading cause of death in the world with three-quarters of cases occurring in countries with middle to low income and half of the cases in Asia (Ohira and Iso, 2013). Cardiovascular disease is a manifestation of the clinical process of atherosclerosis which often happens abruptly and dramatically (AHA, 2016). Atherosclerosis is one of the

\footnotetext{
"Corresponding Author

Siti Khotimah, Doctoral Program of Medical Science,

Faculty of Medicine, Universitas Brawijaya, Malang, Jawa Timur, Indonesia; Department of Biochemistry, Medical Faculty of Mulawarman University, Samarinda, Kalimantan Timur, Indonesia.

Email:st_khotimah@yahoo.com
}

chronic inflammatory disorders that exhibit symptoms caused by the inflammatory process, the formation of foam cells, and the development of atheroma plaque on the subendothelial layer of the blood vessel wall (Heine et al., 2008; Hopkin, 2013; Wu et al., 2017). The formation of foam cell is one of the critical stages in the atherosclerosis process, not only does it relate to lipid metabolism but also the inflammation that it causes can accelerate atherosclerosis progressiveness (Bobryshev et al., 2016).

Lipid metabolism on macrophage covers three processes, namely, cholesterol uptake, esterification, and secretion of the cholesterol (cholesterol efflux). The imbalance between these processes may cause the accumulation of lipids in the cytoplasm of the macrophage forming foam cells (Maguire et al., 2019). The inflammation on the subendothelial layer which is caused by ox-LDL would attract the monocyte of the 
lumen which later activated and became macrophage (Hopkin, 2013; Raggi et al., 2018). The activated macrophage expresses scavenger receptors, one of them is Toll-Like Receptor 4 (TLR4), causing an increase of ox-LDL uptake (Moore and Tabas, 2011). The current studies showed that TLR4 expression is increased in atherosclerosis, whereas deficiency of TLR4 on mice decreases lesion up to $71 \%$ (Cole and Georgiou, 2010). The stimulation of macrophage with ox-LDL would activate the TLR4 receptor and increase the uptake of ox-LDL, which immediately leads to the lipid accumulation in the cell (Keyel et al., 2012). In addition to lipid accumulation, the activation of TLR4 receptor would also increase the expression of pro-inflammatory mediators, such as interleukin-1 $\beta$ (IL-1 $\beta$ ), interleukin-6 (IL-6), and tumor necrosis factor- $\alpha$ (TNF- $\alpha$ ), and promote the degradation on matrix of the atherosclerotic lesion (Falck-Hansen et al., 2013; Higashimori et al., 2011; Shalhoub et al., 2011).

Another mechanism of foam cell formation is through the inhibition of the cholesterol efflux process from macrophage (Yuan et al., 2012). It is known that Adenosine Triphosphatebinding cassette transporter $\mathrm{A} 1 / \mathrm{G} 1$ (ABCA1/ABCG1) protein transporter has an important role in the mechanism of cholesterol efflux and lipid metabolism (Tarling and Edwards, 2011; YvanCharvet et al., 2010). The expression of ABCA1/ABCG1 on macrophage is regulated by the transcription factors of peroxisome-proliferated-activated receptor $\gamma(\operatorname{PPAR} \gamma)$ and liver X receptor (LXR) (Sotherden et al., 2012; Uitz, 2014). The activation of these transcription factors would increase the expression of ABCA1/ABCG1, followed by the increase of cholesterol efflux and the decrease of lipid deposition in the foam cell (Biswas and Mantovani, 2012; Nikolic et al., 2016).

Eleutherine americana Merr. (E. americana), also known as Bawang Dayak in Kalimantan, Indonesia, is one of the medicinal plants that is widely used by the local people as a traditional medicine. Bawang Dayak is used as a medicine for pain relief, intestinal disorder, antifertility agent, and abortion as well as cardiovascular disorders (Ha et al., 2013). Multilevel extraction of the E. americana by using n-hexane with highperformance liquid chromatography identified some Quinone derivate active substances. In addition, the phytochemical evaluation of $E$. americana had successfully identified three groups of Quinone substances such as anthraquinone, naphthoquinone, and naphthalene (Hong, et al., 2008). A meta-analysis study that examined the activity of substances from naphthoquinone group showed that it functioned specifically as an anti-inflammatory agent (Insanu et al., 2014). Some biological activities of $E$. americana have been identified such as anti-dermatophytes and anti-melanogenesis (Kusuma et al., 2010); inhibiting the NO production by macrophage induced with Lipopolysaccharides (Han et al., 2008); as immunomodulator on T helper cell (Hong et al., 2008); as anti-oxidant (Nur, 2011; Nurliani and Santoso, 2012; Pratiwi et al., 2013); inhibitor of inducible nitric oxide synthase (iNOS); and inhibitor of cytokines expression such as IL- $\beta$ and interferon- $\beta$ (IF- $\beta$ ) through inhibition of nuclear factor kappa B (NF-kB) (Song et al., 2009).

Therefore, this study aimed to investigate the antiatherosclerosis activity of n-hexane extract of E. americana on human macrophage induced with ox-LDL.

\section{MATERIALS AND METHODS}

\section{The isolation of monocyte from PBMCs}

This study has previously been examined and approved by the Health Research Ethics Commission of the Faculty of Medicine Universitas Brawijaya Malang, Indonesia (No. 308/EC/KEPK-S3/9/2017). PBMCs were collected from the blood sample of a healthy adult male. Blood donor was required to give informed consent for sampling. The isolation of monocytes was conducted by RosetteSep ${ }^{\mathrm{TM}}$ human monocyte enrichment cocktail following the factory protocol. The blood sample was placed in an Ethylenediaminetetraacetic acid tube and then added with RosetteSep ${ }^{\mathrm{TM}}$ human monocyte enrichment cocktail (Stemcell Technology, \#15068), mixed, and incubated for 20 minutes. The sample was diluted with the recommended medium and mixed slowly. The diluted sample was moved to a tube added with a density gradient medium in accordance with the protocol kit. The sample was centrifuged at $1,200 \mathrm{xg}$ for 10 minutes and the cell was collected, washed, and centrifuged again. Afterward, the cell was diluted in the medium. The monocyte cell as the result of these processes was calculated by using a hemocytometer (Delirezh et al., 2013).

\section{Primary human macrophage cell culture}

The isolated monocytes were placed on a plate that has been added with the medium for culture process containing RPMI-1640, Dulbecco's modified Eagle's medium, fetal bovine serum, and penicillin-streptomycin for 5 days. Cell culture was placed in an incubator at $37^{\circ} \mathrm{C}$ and $5 \% \mathrm{CO}_{2}$ so that the monocytes differentiated and became macrophage. For the treatment group, the n-hexane extract of E. americana was added on the sixth day, incubated for 24 hours, and then used for further experimental research (Safi et al., 2016).

\section{Preparation of n-hexane extract of Eleutherine americana}

The extract of n-hexane Eleutherine americana Merr. was prepared in the Pharmacology Laboratory at the Medical Faculty of Mulawarman University, Samarinda, East Kalimantan, Indonesia. The Bawang Dayak plant was obtained from the local farmer in Samarinda, East Kalimantan. The plant was then preliminarily examined in the Laboratory of Plant Systematics and Anatomy, Faculty of Mathematics and Natural Sciences, Mulawarman University, in order to gain the identification of its taxonomy. About $\pm 2-3 \mathrm{~kg}$ bulbs of Bawang Dayak were well sorted, cleaned, and dried in a cabinet. This process resulted in $\pm 250-500 \mathrm{~g}$ of dried simplisia. After it was well dried, the substance was blended to make smooth dried powder. Dried powder of Bawang Dayak bulb was extracted with methanol $90 \%$ resulting in crude methanol extract. The crude extract was then extracted with methanol and water with $6: 4(\mathrm{v} / \mathrm{v})$ ratio. The crude extract was also extracted with n-hexane in a separate funnel, creating two different extracts. The addition of n-hexane was conducted repeatedly until clear $n$-hexane extract was obtained. The n-hexane extract was concentrated with a rotary evaporator. For the purpose of the experiment, Bawang Dayak extract was diluted in dimethyl sulfoxide for cell culture with the concentration of the final culture $\leq 0.1 \%$ (Ahmad et al., 2016). 


\section{Foam cell formation}

The mature monocytes prepared earlier were placed on a plate and were added with n-hexane Eleutherine extract with a dose of $0.25,1$, and $2 \mathrm{mg} / \mathrm{ml}$ on the sixth day. Cells were incubated for 24 hours before stimulation with $100 \mu \mathrm{g} / \mathrm{ml}$ of oxidized lowdensity lipoproteins in human plasma (Athens Research and Technology; \#12-16-120412-OX). Cells were then incubated again for 48 hours. Afterward, staining was conducted using Oil Red $\mathrm{O}$ and cells were examined under an optical microscope with 640x magnification (Park et al., 2015).

\section{Oil red $O$ staining}

After 48 hours of incubation, monocytes are prepared for staining. The culture medium was slowly decanted through aspiration and carefully not to disturb the cells. Cells were then washed twice with phosphate-buffered saline (PBS) solution. Cells were fixed for 10 minutes with $4 \%$ paraformaldehyde, and then quickly washed with $60 \%$ isopropanol. The lipid staining process was conducted with Oil Red O, Sudan Red 5B (Bioworld; $41540000-2)$ for 15 minutes ( $0.4 \%$ Oil Red in $100 \%$ isopropanol) and then the mixture was quickly washed again with $60 \%$ isopropanol and finally with PBS. Cells were examined under an optical microscope with 640x magnification. For absorbance solubility of Oil Red O examination, $100 \mu 1$ 100\% isopropanol was added and mixed for 10 minutes. The supernatant was moved to a new well and read on the spectrophotometer with $570 \mathrm{~nm}$ wavelength (Ning et al., 2017).

\section{Calculating the percentage of the foam cells}

The number of foam cells was calculated in every 100 cells using a cell counter to calculate foam cell percentage. The foam cell was determined by selecting a cell with red color on its cytoplasm. The red color was formed from lipid droplet on the cytoplasm which was stained by Oil Red O.

\section{Nuclear protein extraction}

For nuclear protein extraction, cells were cultured on a 12-well plate to collect a sufficient number of cells. After the addition of n-hexane extract and ox-LDL, nuclear protein extraction was conducted using RayBio ${ }^{\circledR}$ Nuclear Extraction Kit following the manufacturer protocol. Cells were washed with ice-cold PBS while pipetting up and down gently to disperse the cells. Then, $1 \mathrm{x}$ nuclear extract reagent-I, which was prepared in accordance with the protocol was added to the cells and incubated on ice for 15 minutes. Reagent-II was added, mixed slowly, and incubated on ice for 2 minutes. Cells were centrifuged at $14,000 \mathrm{xg}$ with $4^{\circ} \mathrm{C}$ temperature for 30 seconds before separating the supernatant. Reagent-III was added into the cell pellet, diluted, vortexed for 10 seconds, and incubated on ice for 10 minutes. After this, the tube was vortexed for 10 seconds and incubated on ice for 10 minutes repeatedly until the total time for incubation was 40 minutes. Afterward, the tube was centrifuged $14,000 \mathrm{xg}$ with $4^{\circ} \mathrm{C}$ temperature for 30 minutes. The supernatant was collected and aliquoted into new tubes for further examination. Nuclear protein obtained was weighed using NanoDrop (Chan and Cipolla, 2012).

\section{Determinant of PPAR $\gamma$ transcription factor activity}

Measurement of PPAR $\gamma$ activity was conducted using Enzyme-linked immunosorbent assay (ELISA). A doublestranded oligonucleotide labeled 96-well plate was used as the place of PPAR $\gamma$ bonding. The oligonucleotide would specifically catch active PPAR $\gamma$ from the shortly incubated nuclear protein. The PPAR $\gamma$ activity of the obtained nuclear protein is measured using Raybio ${ }^{\mathbb{R}}$ Human PPAR $\gamma$ transcription factor Activity Assay Kit according to the manufacturer protocol. Each well was filled with appropriate reagent and then the primary antibody for PPAR $\gamma$ was added to the well and incubated for 1 hour. After washing, 3,3',5,5'-tetramethylbenzidine One-Step Substrate Reagent was added and incubated for 30 minutes. After this step, the stop solution was added and the result was immediately read on the ELISA reader of $450 \mathrm{~nm}$ wavelength (Chan and Cipolla, 2012).

\section{Immunofluorescence staining}

Cells from the treatment and control group were harvested and fixed with 4\% paraformaldehyde in PBS at $\mathrm{pH} 7.4$ for 10 minutes at room temperature. Immunofluorescence staining was used to measure the expression of TLR4, ABCA1, and ABCG1 proteins through a confocal microscope. The antibodies used were mouse monoclonal IgG ABC1 (Santa Cruz Biotechnology, Inc.; \#A00121.01), rabbit anti ABCG1 polyclonal antibody (Bioss Inc.; \#bs-4906R), mouse monoclonal IgG TLR4 (\#HTA 125), goat antimouse IgG H and L [Fluorescein isothiocyanate (FTIC)] secondary antibody from Abcam (\#ab6785), and goat anti-rabbit IgG H and L (Rhodamine) secondary antibody from Invitrogen (\#31670). Cell permeabilization was done by adding $0.1 \%-0.25 \%$ Triton-X 100 in PBS and then incubated for 10 minutes. The cells were then washed three times. Blocking was conducted by adding $1 \%$ bovine serum albumin (BSA), $22.52 \mathrm{mg} / \mathrm{ml}$ glycine in Phosphate Buffered Saline Tween-20 (PBST) (PBS+ 0.1\% Tween 20) for 30 minutes. Cells were then incubated in primary antibody which was diluted in $1 \%$ BSA in PBST overnight at $4^{\circ} \mathrm{C}$ temperature. The primary antibody solution was discarded and cells were washed with PBS three times for 5 minutes each. Cells were then incubated in a secondary antibody in $1 \%$ BSA for 1 hour in the darkroom at room temperature. The secondary antibody solution was discarded and cells were washed three times with PBS for 5 minutes each in the darkroom. Coverslip was installed before cells were examined under the microscope (Wang et al., 2018).

\section{Statistical analysis}

We performed analysis of variance for statistical analysis as appropriate. The significances were then ranked using Least significant different-ANOVA analysis with $95 \%$ confidence intervals. Values are expressed as the mean and \pm standard error of mean (SEM). All the tests were carried out using SPSS version 23.

\section{RESULTS AND DISCUSSION}

\section{The effect of n-hexane extract of Eleutherine americana in inhibiting foam cell formation on ox-LDL stimulated macrophage}

The purpose of this research was to prove whether the n-hexane extract of E. americana was able to inhibit the formation of macrophage-derived foam cell in vitro. Macrophage foam 
cell is formed through the increase of ox-LDL uptake into the macrophages without adequate cholesterol lipid efflux. Foam cell is marked by the presence of lipid deposits in the cytoplasm of macrophages which is microscopically visible with Oil Red O staining (red color) (Fig. 1a). The monocytes isolated from PBMCs, after undergoing differentiation, were incubated with n-hexane extract of $E$. americana with the dosage of $0.25,1$ and $2 \mathrm{mg} / \mathrm{ml}$. We demonstrated that the percentage of the foam cells was decreased in the treatment group that was given n-hexane extract compared with the control group which was only given ox-LDL that seemed to be dose-dependent (Fig. 1b). Identically, the result of the examination using absorbance of Oil Red $\mathrm{O}$ on a spectrophotometer, which indirectly exposed the content of lipid in the cells, showed that there was a decrease of lipid content in the treatment group compared to the control group that seemed to be dose-dependent (Fig. 1c)

The results of this study showed, for the first time, that the n-hexane extract of E. americana demonstrated anti-atherosclerotic activity. This was demonstrated through its capability in inhibiting the formation of foam cells on ox-LDL induced macrophages. Foam cells formation can be inhibited through either the ox-LDL uptake mechanism or cholesterol efflux from macrophages. The balance between the two processes is important in maintaining a normal level of intra-cell lipid. On the contrary, cell failure in balancing the two mechanisms can lead to excessive lipid accumulation which results in the acceleration of apoptosis and cell necrosis and finally manifested as atherosclerotic plaque (Yu et al., 2013).

Previous studies have provided ample evidence that natural substance extracts possess anti-atherosclerotic activity. Some biological activities related to anti-atherosclerosis from natural substances under empirical research were Zanthoxylum heitzii as anti-oxidative stress (Ntchapda et al., 2015), Premna integrifolia Linn. that demonstrated ability to improve the lipid profile, atherogenic index, cardiac marker, and atherosclerotic lesion on mice fed with high-fat diet (Subramani et al., 2017), and Salviae Miltiorrhizae Radix et Rhizoma that showed antiatherosclerotic effect, anti-inflammatory effect, and protection against of oxidative damage (Li et al., 2018; Pang et al., 2016).

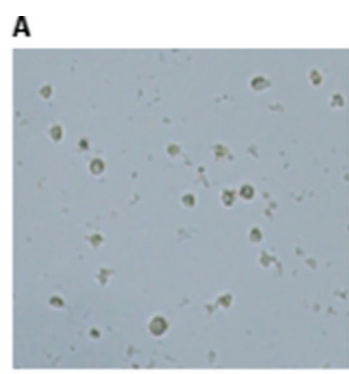

Control

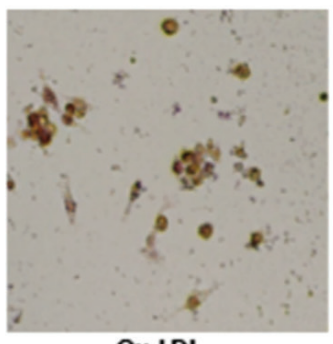

Ox-LDL

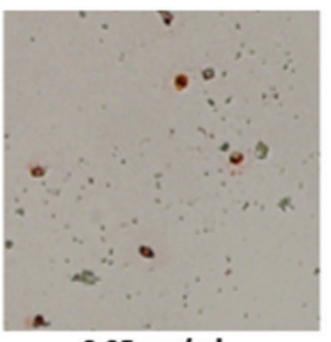

$0.25 \mathrm{mg} / \mathrm{ml}$

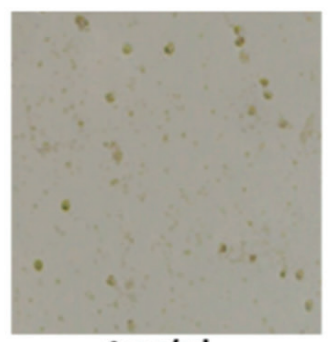

$1 \mathrm{mg} / \mathrm{ml}$

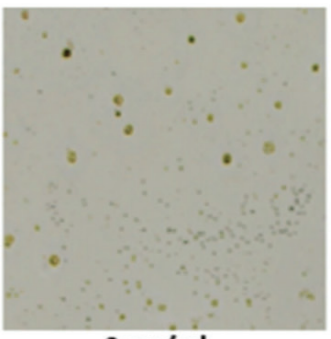

$2 \mathrm{mg} / \mathrm{ml}$

Eleutherine + ox-LDI
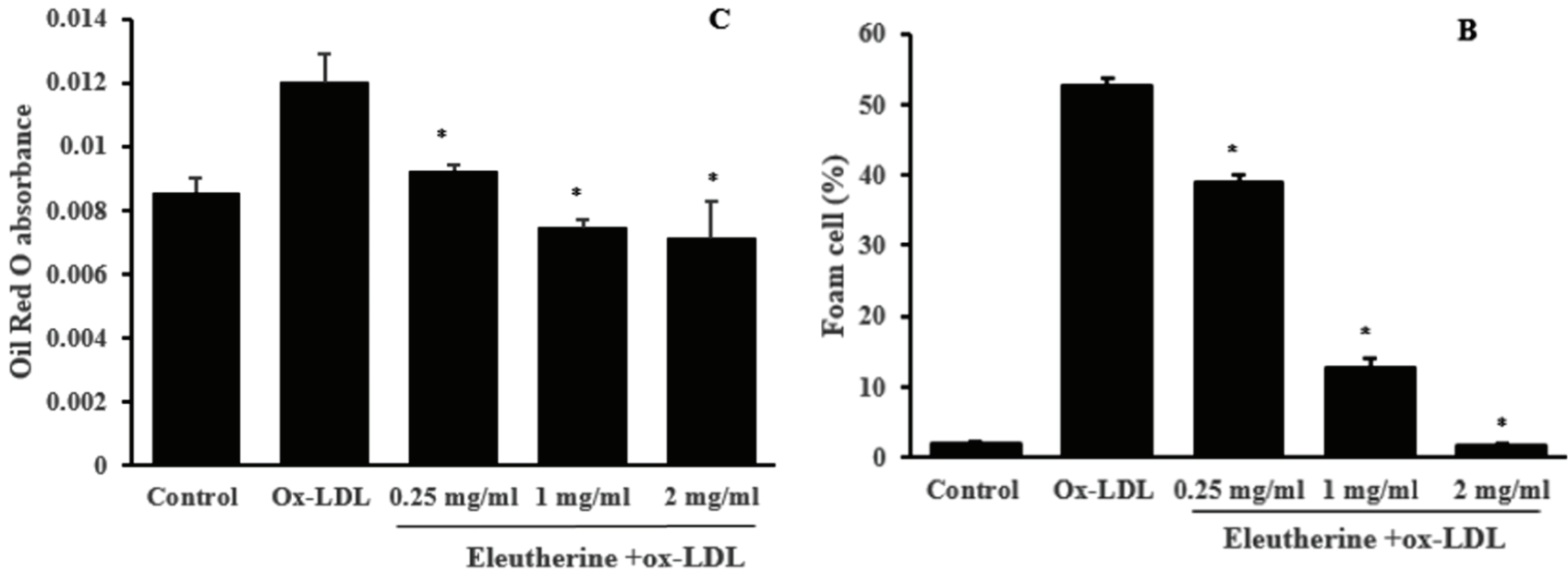

Figure 1. Effects of n-hexane extract of E. americana administration in inhibiting foam cell formation in ox-LDL stimulated macrophages. (a) Monocytes originating from PBMCs, after underwent differentiation, were given n-hexane extract with a dose of 0.25 , 1 , and $2 \mathrm{mg} / \mathrm{ml}$, incubated for 24 hours, and then stimulated with $100 \mu \mathrm{g} / \mathrm{ml}$ ox-LDL. After 48 hours of incubation, cells were stained with Oil Red O. The red color indicated the lipid stained by Oil Red O. (b) The number of foam cells was computed by the cell counter. (c) The macrophages stained with Oil Red O were added with $100 \mu 1$ isopropanol $100 \%$ for 10 minutes and were read on spectrophotometer $570 \mathrm{~nm}$ wavelength. All data are presented as mean \pm SEM, ${ }^{*} p<0.05$ compared to the ox-LDL group. 
The effect of n-hexane extract of Eleutherine americana in decreasing of TLR4 protein expression on ox-LDL stimulated macrophage

TLR4 is a membrane protein expressed by macrophage which is activated by a foreign object like ox-LDL that acts as a scavenger receptor. We used immunofluorescence staining to examine the effect of the n-hexane extract of E. americana in decreasing TLR4 expression. The treatment group that was given $\mathrm{n}$-hexane extract with various dosages showed a decrease in the intensity of TLR4 expression. This effect seemed to be dosedependent. A significant decrease occurred in the treatment group given 1 and $2 \mathrm{mg} / \mathrm{ml}$ of $\mathrm{n}$-hexane extract compared to the control group that was given ox-LDL (Fig. 2).

This study also proved that the n-hexane extract of $E$. americana were able to decrease the expression of TLR4 receptor. The TLR4, besides being responsible for activating the cascade of cellular inflammation through NF-kB, has been identified as the receptor that increases the uptake of ox-LDL into the cell (FalckHansen et al., 2013). By decreasing TLR4 expression on the macrophage, the uptake of ox-LDL into the macrophages would also be reduced resulting in less foam cell formation. Another study found that mice with TLR 4 - deficiency that was fed with a high-fat diet for 6 months has a decreased size of atherosclerotic lesions, lipid content, and macrophage infiltration (Higashimori et al., 2011; Mahmoudi, 2016). This study demonstrated that TLR4 has a vital role in the process of cholesterol uptake into the macrophages.

\section{The effect of n-hexane extract of Eleutherine americana in increasing $\mathrm{ABCA} 1$ and $\mathrm{ABCG} 1$ expression on ox-LDL stimulated macrophage}

ABCA1 and ABCG1 are transporter proteins that have an important role in lipid transport from intracellular to extracellular to be caught by Apo-AI and high-density lipoprotein in the cholesterol efflux mechanism. We used double-staining immunofluorescence to examine the effect of n-hexane extract of E. americana toward ABCA1 and ABCG1 expression. The treatment group that was given n-hexane extract with various dosage demonstrated an increase in the protein expression of both ABCA1 and ABCG1 that seemed to be dose-dependent compared to the control group that was given only ox-LDL (Fig. 3).

The increase in ABCA1 and ABCG1 protein expression on ox-LDL stimulated macrophages showed that the n-hexane extract of $E$. americana has a positive effect on intracellular cholesterol metabolism. ABCA1 and ABCG1 are very important for cholesterol transport in cholesterol efflux (Yvan-Charvet et al., 2010). Cholesterol efflux is a vital mechanism in cellular cholesterol homeostasis as a response to the fluctuation of cholesterol uptake. (Park et al., 2012) On the other hand, imbalance between cholesterol uptake and cholesterol efflux is the basis for intracellular lipid deposition that leads to foam cells formation. In the end, excessive accumulation of intracellular cholesterol would cause cellular toxicity and cell death (Yuan et al., 2012). In this study, n-hexane extract of E. americana was proven to improve intracellular cholesterol circulation simultaneously through both the uptake and the secretion process. This confirms the effectiveness of E. americana as a modulator of cholesterol homeostasis in macrophages.

In this study, administration of n-hexane extract of $E$. americana, despite being able to increase the protein expression of ABCA1 and ABCG1, did not affect the activity of PPAR $\gamma$ transcription factor (Fig. 4). This effect is contrary to the result demonstrated by Matsumura et al. (2011) in which Telmisartan increased the expression of ABCA1 and ABCG1 through activation of PPAR $\gamma$. The expression of ABCA1 and ABCG1 is regulated by PPAR $\gamma$ and LXR nucleus receptors, both will activate the genes responsible for the expression of ABCA1 and ABCG1 (Remmerie and Scott, 2018). It is possible that n-hexane extract of $E$. americana increased the expression of ABCA1 and ABCG1 through the LXR pathway directly. Nevertheless, this has not been proven. Another study has shown that increased expression of ABCA1 and ABCG1 occurred through activation of the LXR nucleus receptor (Iizuka et al., 2012). Meanwhile, there is also a study that proved that PPAR $\gamma$ and LXR work collaboratively through the PPAR $\gamma / \mathrm{LXR}$ pathway axis in regulating ABCA1 and
A

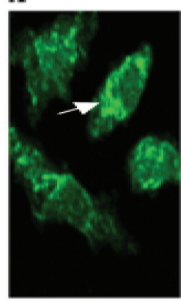

Control

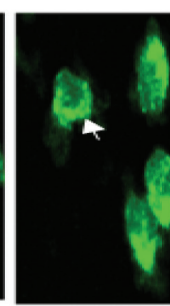

0r-LDL
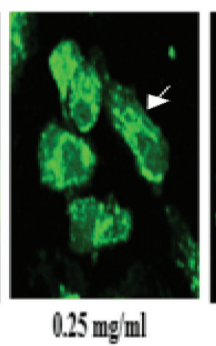

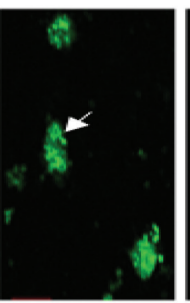

$1 \mathrm{mg} m \mathrm{ml}$

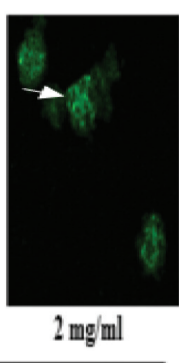

Eleutherine + or-LDL

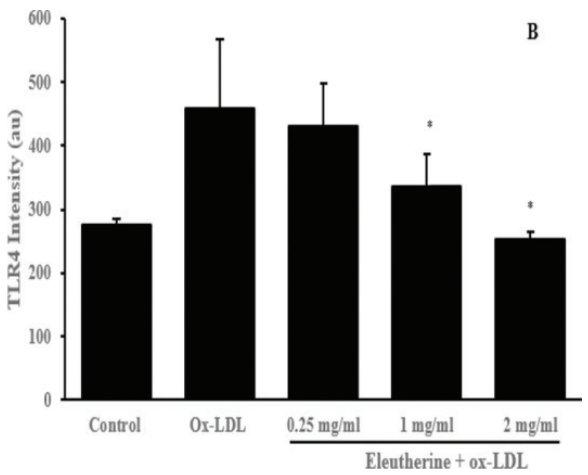

Figure 2. Administration of n-hexane extract of $E$. americana was able to reduce TLR4 protein expression in human macrophages stimulated with ox-LDL. In picture (a) macrophages derived from PBMCs were given n-hexane extract of $0.25,1$, and 2 mg/ml dosage, incubated for 24 hours, and then stimulated with $100 \mu \mathrm{g} / \mathrm{ml}$ ox-LDL. After 48 hours of incubation, cells were fixed with $4 \%$ paraformaldehyde and immunofluorescence staining was performed using mouse monoclonal IgG TLR4 primary antibody and goat anti-mouse IgG H and L (FITC) secondary antibody. The result observed with a confocal microscope demonstrated different levels of intensity (green color) that showed TLR4 protein expression. (b) The result of quantitative color intensity measurements in the treatment group given n-hexane extract of 1 and $2 \mathrm{mg} / \mathrm{ml}$ dosage was decreased $* p=0.008$ and 0.000 compared to the control group that was given ox-LDL. All data are presented as mean $\pm \mathrm{SEM}$. 

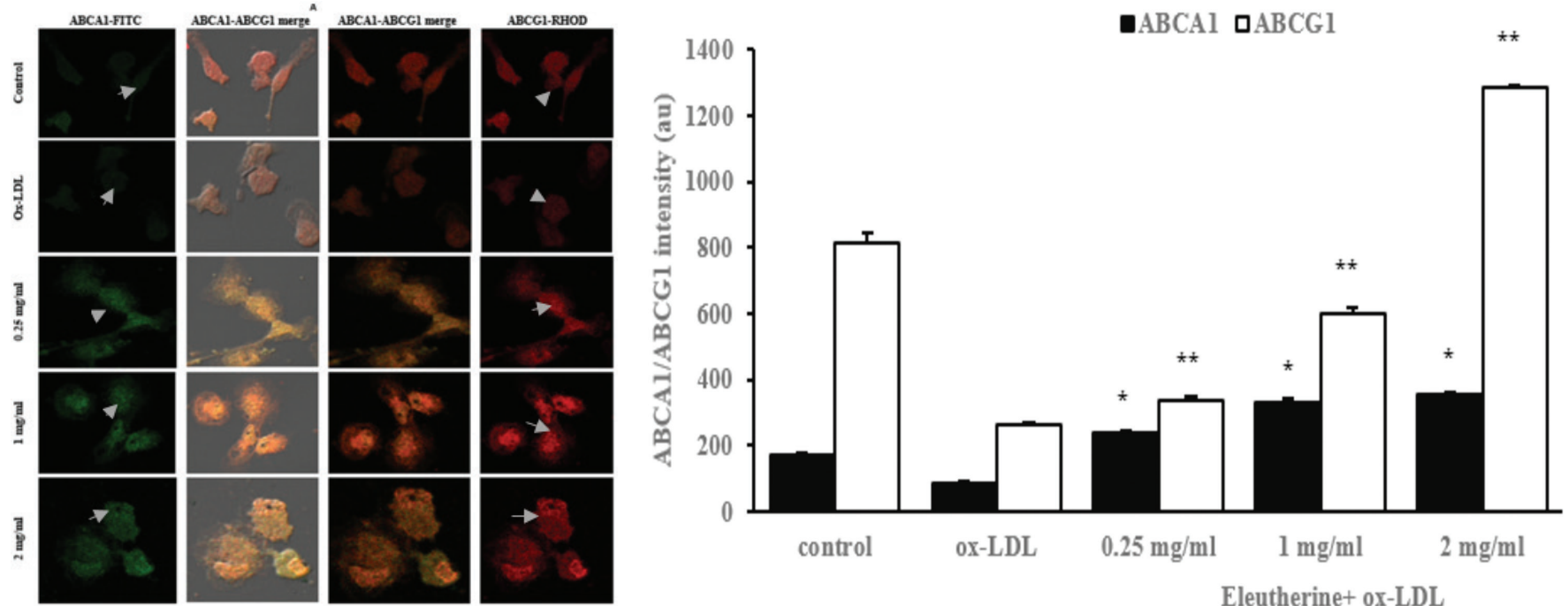

Figure 3. Administration of n-hexane extract of E. americana was able to increase the ABCA1 and ABCG1 protein expression in human macrophages stimulated with ox-LDL. (a) Macrophages derived from PBMCs were given n-hexane extract of $0.25,1$, and $2 \mathrm{mg} / \mathrm{ml}$ dosage, incubated for 24 hours, then stimulated with $100 \mu \mathrm{g} / \mathrm{ml}$ ox-LDL. After 48 hours of incubation, cells were fixed with $4 \%$ paraformaldehyde and double staining immunofluorescence was performed. In (a), the result observed with a confocal microscope demonstrated different levels of intensity (green color) that showed ABCA1 expression, while the red color showed ABCG1 protein expression. (b) The result of quantitative color intensity measurements in the treatment group was decreased compared to the control group with ${ }^{*} p=0.000$. All data are presented as mean $\pm \mathrm{SEM}$.

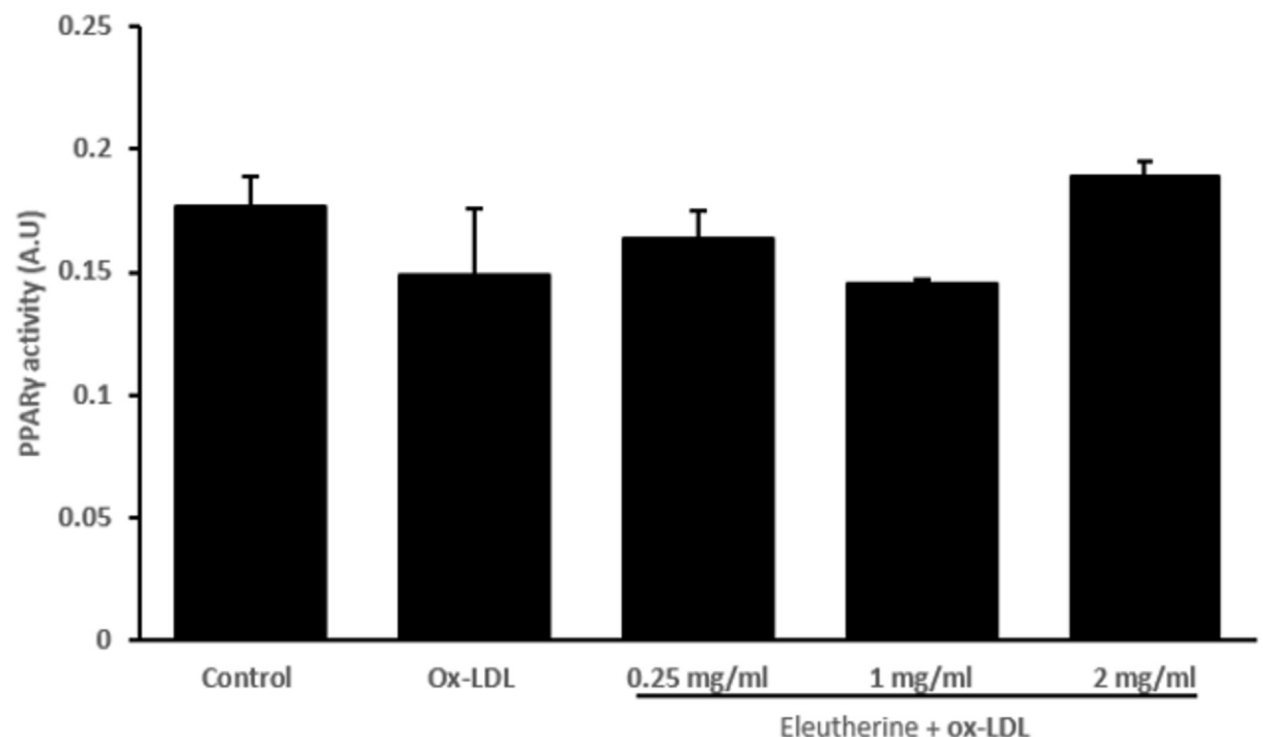

Figure 4. Administration of n-hexane extract of E. americana had no effect in increasing PPAR $\gamma$ activity in human macrophages stimulated with ox-LDL in vitro. Macrophages derived from PBMCs were given n-hexane extract of $0.25,1$, and $2 \mathrm{mg} / \mathrm{ml}$ dosage, incubated for 24 hours, then stimulated with $100 \mu \mathrm{g} / \mathrm{ml} \mathrm{ox}-\mathrm{LDL}$. In the group given n-hexane extract, there was an increase in PPAR $\gamma$ activity but was not significant compared to the control group given ox-LDL only. All data are presented as mean \pm SEM.

ABCG1 expression (Jiang et al., 2017). The result of this study provides the basis for further research on the mechanism of $E$. americana in inhibiting atherosclerosis so that it can be used as one of the approaches in the treatment of atherosclerosis.

\section{CONCLUSION}

We conclude that the n-hexane extract of E. americana was proven to have an anti-atherosclerotic activity by inhibiting foam cell formation through decreasing the ox-LDL uptake and increasing cholesterol efflux simultaneously.

\section{ACKNOWLEDGMENT}

Acknowledgments were conveyed to Bunga Prihardina, S.Si, Ami Maghfironi, S.Si, Wahyudha Ngatiril Lady, S.Si and Choirunil Chotimah, S.Si, M.Si who provided technical assistance in this study. 


\section{CONFLICT OF INTEREST}

The authors declare that they have no conflicts of interest.

\section{REFERENCES}

Ahmad I, Arifuddin M, Rijai L. The effect of extraction methods of Bawang Dayak (Eleutherine palmifolia 1. merr) against tlc profiles and sunscreen activities. Int J Pharm Tech Res, 2016; 9(9):428-36.

American Heart Association (AHA). Heart disease and stroke statistic-update 2016. A report from American Heart Association, 2016. Available via http://circ.ahajournals.org/ (Accessed 27 June 2016).

Biswas SK, Mantovani A. Orchestration of metabolism by macrophages. Cell Metab, 2012; 15(4):432-7.

Bobryshev YV, Ivanova EA, Chistiakov DA, Nikiforov NG, Orekhov AN. Macrophages and their role in atherosclerosis: pathophysiology and transcriptome analysis. BioMed Res Int, 2016; 2016:1-13.

Chan S-L, Cipolla MJ. Determination of PPAR $\gamma$ activity in adipose tissue and spleen. J Immunoass Immunochem, 2012; 29(3):9971003.

Cole JE, Georgiou E. The expression and functions of toll-like receptors in atherosclerosis. London, UK: Hindawi Publishing Corporation, pp 1-18, 2010.

Delirezh N, Shojaeefar E, Parvin P, Asadi B. Comparison the effects of two monocyte isolation methods, plastic adherence and magnetic activated cell sorting methods, on phagocytic activity of generated dendritic cells. Cell J, 2013; 15(3):218-23.

Falck-Hansen M, Kassiteridi C, Monaco C. Toll-Like Receptors in atherosclerosis. Int J Mol Sci, 2013; 14(7):14008-23.

Ha LM, Huyen DTT, Kiem PVan, Minh C, Van Van NTH, Nhiem NX, Kim YH. Chemical constituents of the rhizome of Eleutherine bulbosa and their inhibitory effect on the pro-inflammatory cytokines production in lipopolysaccharide -stimulated bone marrow-derived dendritic cells. $\mathrm{J}$ Chem Inf Model, 2013; 53(1):1689-99.

Han AR, Min HY, Nam JW, Lee NY, Wiryawan A, Suprapto W, Seo EK. Identification of a new naphthalene and its derivatives from the bulb of Eleutherine americana with inhibitory activity on lipopolysaccharideinduced nitric oxide production. Chem Pharm Bull, 2008; 56(9):1314-26.

Heine GH, Ulrich C, Seibert E, Seiler S, Marell J, Reichart B, Girndt M. CD14(++), CD16+ monocytes but not total monocyte numbers predict cardiovascular events in dialysis patients. Kidney Int, 2008; 73(5):622-9.

Higashimori M, Tatro JB, Moore KJ, Mendelsohn ME, Galper $\mathrm{JB}$, Beasley D. Role of toll-like receptor 4 in intimal foam cell accumulation in apolipoprotein E-deficient mice. Arterioscler Thromb Vasc Biol, 2011; 31(1):50-7.

Hong JH, Yu ES, Han AR, Nam JW, Seo EK, Hwang ES. Isoeleutherin and eleutherinol, naturally occurring selective modulators of Th cell-mediated immune responses. Biochem Biophys Res Commun, 2008; 371(2):278-82.

Hopkin PN. Molecular biology of atherosclerosis. Physiol Rev, 2013; 93:1317-542.

Iizuka M, Ayaori M, Uto-Kondo H, Yakushiji E, Takiguchi S, Nakaya K, Ikewaki K. Astaxanthin enhances ATP-binding cassette transporter A1/G1 expressions and cholesterol efflux from macrophages. J Nut Sci Vitaminol, 2012; 58(2):96-104.

Insanu M, Kusmardiyani S, Hartati R. Recent studies on phytochemicals and pharmacological effects of Eleutherine americana Merr. Procedia Chem, 2014; 13:221-8.

Jiang T, Ren K, Chen Q, Li H, Yao R, Hu H, Zhao GJ. Leonurine prevents atherosclerosis via promoting the expression of ABCA1 and ABCG1 in a PPAR $\gamma /$ Lxr $\alpha$ signaling pathway-dependent manner. Cell Physiol Biochem, 2017; 43(4):1703-17.

Keyel PA, Tkacheva OA, Larregina AT, Salter RD. Coordinate stimulation of macrophages by microparticles and TLR ligands induces foam cell formation. J Immunol, 2012; 189(9):4621-9.
Kusuma IW, Arung ET, Rosamah E, Purwatiningsih S, Kuspradini $\mathrm{H}$, Syafrizal Shimizu K. Antidermatophyte and antimelanogenesis compound from Eleutherine americana grown in Indonesia. J Nat Med, 2010; 64(2):223-6.

Li GH, Li YR, Jiao P, Zhao Y, Hu HX, Lou HX, Shen T. Therapeutic potential of Salviae Miltiorrhizae Radix et Rhizoma against human diseases based on activation of Nrf2-mediated antioxidant defense system: bioactive constituents and mechanism of action. Oxidative Med Cell Longevity, 2018; 2018:1-13.

Maguire EM, Pearce SWA, Xiao Q. Foam cell formation: a new target for fighting atherosclerosis and cardiovascular disease. Vasc Pharmacol, 2019; 112:54-71.

Mahmoudi, M. The role of TLR2, TLR4, and TLR9 in the pathogenesis of atherosclerosis. Medicine (United Kingdom), 2016; 46(9):505-8.

Matsumura T, Kinoshita H, Ishii N, Fukuda K, Motoshima H, Senokuchi T, Taketa K, Kawasaki S, Nishimaki-Mogami T, Kawada T, Nishikawa T, Araki, E. Telmisartan exerts antiatherosclerotic effects by activating peroxisome proliferator-activated receptor- $\gamma$ in macrophages. Arterioscle Thromb Vasc Biol, 2011; 31(6):1268-75.

Moore KJ, Tabas I. Macrophages in the pathogenesis of atherosclerosis. Cell, 2011; 145(3):341-55.

Nikolic D, Castellino G, Banach M, Toth P, Ivanova E, Orekhov A, Rizzo M. PPAR agonists, atherogenic dyslipidemia and cardiovascular risk. Curr Pharm Design, 2016; 23(6):894-902.

Ning H, Liu D, Yu X, Guan X. Oxidized low-density lipoproteininduced p62/SQSTM1 accumulation in THP-1-derived macrophages promotes IL-18 secretion and cell death. Exp Ther Med, 2017; 14(6): 5417-23.

Ntchapda F, Maguirgue K, Adjia H, Etet PFS, Dimo $\mathrm{T}$. Hypolipidemic, antioxidant and anti-atherosclerogenic effects of aqueous extract of Zanthoxylum heitzii stem bark in diet-induced hypercholesterolemic rats. Asian Pacific J Trop Med, 2015; 8(5):359-65.

Nur AM. Kapasitas antioksidan Bawang Dayak (eleutherine palmifolia) dalam bentuk segar,simplisia dan keripik, pada pelarut nonpolar, semipolar dan polar. Department of Food Science and Technology, Faculty of Agricultural Technology, Bogor Agricultural University, Repository of IPB, Bogor, Jawa Barat, Indonesia, 2011

Nurliani A, Santoso HB. Efek antioksidan ekstrak bulbus bawang dayak (Eleutherine palmifolia) pada gambaran histopatologis paruparu tikus yang dipapar asap rokok. Bioscientiae, 2012; 9:60-9.

Ohira T, Iso H. Cardiovascular disease epidemiology in Asia An overview. Circ J, 2013; 77(7):1646-52.

Pang H, Wu L, Tang Y, Zhou G, Qu C, Duan JA. Chemical analysis of the herbal medicine salviae miltiorrhizae radix et rhizoma (Danshen). Molecules, 2016; 21(1):1-28.

Park SH, Hun Paek J, Shin D, Lee JY, Lim SS, Kang YH. Purple perilla extracts with $\alpha$-asarone enhance cholesterol efflux from oxidized LDL-exposed macrophages. Int J Mol Med. 2015; 35(4):957-65.

Park SH, Kim JL, Kang MK, Gong JH, Han SY, Shim JH, Kang YH. Sage weed (Salvia plebeia) extract antagonizes foam cell formation and promotes cholesterol efflux in murine macrophages. Int J Mol Med, 2012; 30(5):1105-12.

Pratiwi D, Wahdaningsih S, Isnindar I. The test of antioxidant activity from Bawang Mekah leaves (Eleutherine americana Merr.) Using dpph (2,2- diphenyl-1-picrylhydrazyl) method. Trad Med J, 2013;10-11.

Raggi P, Genest J, Giles JT, Rayner KJ, Dwivedi G, Beanlands RS, Gupta M. Role of inflammation in the pathogenesis of atherosclerosis and therapeutic interventions. Atherosclerosis, 2018; 276:98-108.

Remmerie A, Scott CL. Macrophages and lipid metabolism. Cell Immunol, 2018; 330:27-42.

Safi W, Kuehnl A, Nüssler A, Eckstein HH, Pelisek J. Differentiation of human CD14+ monocytes: an experimental investigation of the optimal culture medium and evidence of a lack of differentiation along the endothelial line. Exp Mol Med. 2016; 48:1-9. 
Shalhoub J, Falck-Hansen Ma, Davies AH, Monaco C. Innate immunity and monocyte-macrophage activation in atherosclerosis. J Inflamm, 2011; 8(1):1-17.

Song SH, Min HY, Han AR, Nam JW, Seo EK, Seoung Woo Park, Sang Kook Lee. Suppression of inducible nitric oxide synthase by $(-)$-isoeleutherin from the bulbs of Eleutherine americana through the regulation of NF-KB activity. Int Immunopharmacol, 2009; 9(3):298-302.

Sotherden GM, Uto-kondo H, Ayaori M, Ikewaki K. Effects of nutraceuticals and botanicals on cholesterol efflux : implications for atherosclerosis macrophage. J Nut Therap, 2012; 1:96-106.

Subramani C, Rajakkannu A, Rathinam A, Gaidhani S, Raju I, Kartar Singh DV. Anti-atherosclerotic activity of root bark of Premna integrifolia Linn. in high fat diet induced atherosclerosis model rats. J Pharm Anal, 2017; 7(2):123-8.

Tarling EJ, Edwards PA. ATP binding cassette transporter G1 (ABCG1) is an intracellular sterol transporter. PNAS, 2011; 108(49): 19719-24.

Uitz E. Practical strategies for modulating foam cell formation and behavior. World J Clin Cases, 2014; 2(10):497-506.

Wang H, Yang Y, Sun X, Tian F, Guo S, Wang W, Tian Y. Sonodynamic therapy-induced foam cells apoptosis activates the phagocytic PPAR $\gamma-\mathrm{LXR} \alpha-\mathrm{ABCA} 1 / \mathrm{ABCG} 1$ pathway and promotes cholesterol efflux in advanced plaque. Theranostics, 2018; 8(18):4969-84.
Wu MY, Li CJ, Hou MF, Chu PY. New insights into the role of inflammation in the pathogenesis of atherosclerosis. Int J Mol Sci, 2017; 18(10).

Yu X, Fu Y, Zhang D, Yin K, Tang C. Foam cells in atherosclerosis. Clinica Chimica Acta, 2013; 424:245-52.

Yuan Y, Li P, Ye J. Lipid homeostasis and the formation of macrophage-derived foam cells in atherosclerosis. Protein and Cell, 2012; 3(3):173-81.

Yvan-Charvet L, Wang N, Tall AR. Role of HDL, ABCA1, and ABCG1 transporters in cholesterol efflux and immune responses. Arterioscler Thromb Vasc Biol, 2010; 30(2):139-43.

How to cite this article:

Khotimah S, Kalim H, Rohman MS, Soeharto S. Antiatherosclerotic activity of N-Hexane extract of Eleutherine americana Merr. on human macrophage primary cell culture. J Appl Pharm Sci, 2020; 10(03):044-051. 